\title{
People and protected areas: a study of local perceptions of wildlife crop-damage conflict in an area bordering the Selous Game Reserve, Tanzania
}

\author{
Sarah Gillingham and Phyllis C. Lee
}

\begin{abstract}
This paper presents an analysis of perceived patterns of wildlife crop-damage in relation to an onfarm assessment of damage in an area bordering the Selous Game Reserve (SGR) in south-eastern Tanzania. Data from an attitudinal questionnaire survey of 202 households in four villages are used to examine local perceptions of wildlife crop-damage in terms of relative impact and which wildlife species were responsible. We explore the influence of wildlife crop-damage on attitudes to the adjacent game reserve. Data on the frequency of crop-damage events and estimated severity of impacts, recorded during a 6-month programme of crop-damage monitoring in one of the survey villages, are used to
\end{abstract}

describe on-farm patterns of crop-damage. Comparison of the two data sets indicates a disjunction between the nature of the wildlife crop-damage conflict as perceived by local villagers, and as it actually occurs in the study area. This disjunction is discussed in relation to the effect of extreme damage events on local people's views, the opportunity costs involved in guarding farm plots against crop-damage, and the tenure arrangements for wildlife that define the relationship with the state wildlife management authority.

Keywords Crop-damage, Selous Game Reserve, Tanzania, wildlife conflict.

\section{Introduction}

The effective long-term conservation of wildlife in and around protected areas requires the support of the people who experience the direct impacts of the establishment and management of those areas (Kiss, 1990; Western \& Wright, 1994). Local people cannot be expected to provide this support if the costs of doing so outweigh the benefits, i.e. if the existence of the protected area and its wildlife have negative impacts on local livelihoods (Murphree, 1996). An understanding of the relationship between a protected area and its surrounding human population in terms of these costs and benefits is therefore crucial to the design and implementation of projects seeking to promote conservation with development (Newmark et al., 1994).

In many parts of Africa local people report conflicts with wildlife over damage to crops, property and the threat posed by wildlife to human life as a significant cost of living adjacent to protected areas (Parry \& Campbell, 1992; Kangwana, 1993; Newmark et al., 1994; Naughton-Treves, 1996; Hill, 1997a); Weladji \& Tchamba 2003). Of these problems, wildlife crop-damage is often

Sarah Gillingham (Corresponding author) and Phyllis C. Lee Department of Biological Anthropology, University of Cambridge, Downing St, Cambridge, UK. E-mail: gillinghms@aol.com

Received 25 March 2002. Revision requested 9 September 2002. Accepted 20 May 2003 the major cause of human-wildlife conflict, particularly in situations where the lands of agriculturalist communities border protected areas. Thus a survey of local people living adjacent to six protected areas in Tanzania found that $86 \%$ of respondents $(n=1,396)$ reported problems with wildlife causing crop-damage (Newmark et al., 1994). High proportions of respondents also reported wildlife crop-damage as a source of conflict in studies carried out around protected areas in Botswana (Parry \& Campbell, 1992), Uganda (Hill, 1997) and Kenya (Kangwana, 1993).

Although most studies of wildlife crop-damage are based on surveys of local peoples' perceptions of the problem and its impacts, it is recognized that the perceived and actual costs of such conflicts do not always match (Bell, 1984; Kangwana, 1993; Naughton-Treves, 1997; Siex \& Struhsaker, 1999). This presents a dilemma for state wildlife management authorities faced with the demands of local communities for problem animal control. This paper presents an analysis of perceived patterns of wildlife crop-damage in an area along the northern border of the Selous Game Reserve in southeastern Tanzania. Questionnaire data from a survey of four villages are used to examine local perceptions of, and tolerance for, wildlife crop-damage, and the influence of wildlife crop-damage on local attitudes to the adjacent game reserve. Data on incidents of wildlife crop-damage recorded during a 6-month monitoring programme in one of the four study villages are then 
presented for comparison with the findings of the questionnaire survey. This comparison provides the basis for a discussion of the nature and scale of conflict in the study area, allowing for the identification of factors contributing to local perceptions of crop-damage as a major problem. We conclude by considering the implications for the design and implementation of projects seeking to achieve conservation with development objectives.

\section{Study area}

This study was carried out in the Mgeta River Buffer Zone (MRBZ) that lies along the northern boundary of the Selous Game Reserve (SGR) in south-eastern Tanzania (Fig. 1). The SGR is a protected area of exceptional conservation value that has been designated as a World Heritage Site, but that has also experienced a long history of human-wildlife conflict in the villages along its boundaries (Rodgers \& Lobo, 1982). Following heavy commercial poaching in the reserve in the late 1970s and 1980s, the Selous Conservation Programme (SCP) was established in 1988 to safeguard the ecological integrity of the SGR, and to promote improved relations between the reserve and its neighbouring human population based on community participation in wildlife management and local access to wildlife benefits (SCP Project Brief, 1994). Implementation of the SCP community wildlife management initiative involved the establishment of five buffer zones bordering the SGR. Community wildlife management activities in the buffer zones include consultative land-use planning leading to the demarcation of Wildlife Management Areas on village lands, financial support for small-scale self-help and community development projects, the allocation of village wildlife quotas to provide game meat to local people at affordable prices, and the establishment of local-level wildlife management institutions in the form of Village Wildlife Committees and Village Scouts (Baldus, 1991). The MRBZ was the first area in which SCP began community wildlife management activities because it had been a recognized 'hotspot' of commercial poaching during the 1980s (Gillingham, 1998).

The MRBZ occupies an area of $1,670 \mathrm{~km}^{2}$ between the Mgeta River and the Uluguru mountains in Morogoro Rural District, of which c. $60 \%$ remains under natural habitat (Ardhi Institute, 1991). The buffer zone is characterized by fertile soils and a tropical climate with a single rainy season from November to May (annual rainfall 900-1,200 mm), which make it an area of recognized agricultural potential (see Gillingham, 1998, for a detailed description). The well-watered Gonabisi grasslands of the Mgeta floodplain, which form the buffer zone's dominant topographical feature, support large concentrations of wildlife, particularly during the dry season when animals disperse out of the SGR in search of water and forage (TWCM, 1995).

Most of the villages in the MRBZ are some distance from the game reserve boundary. Because a system of

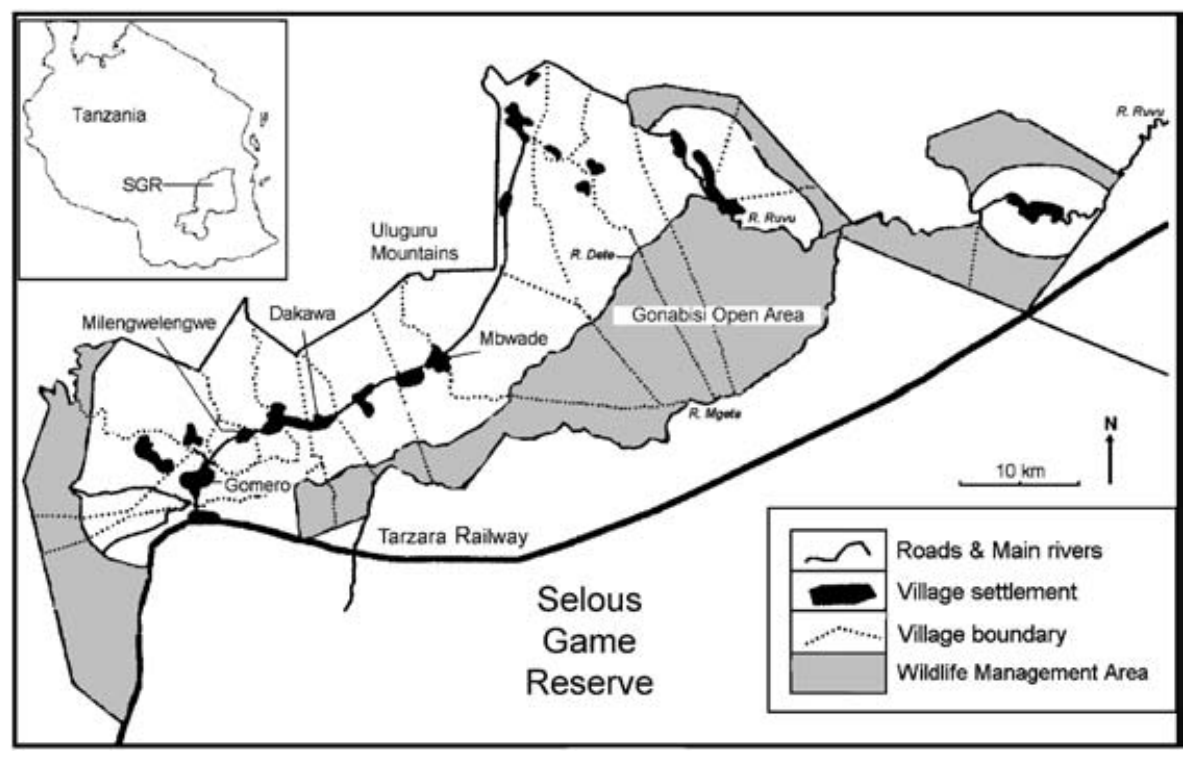

Fig. 1 Map of the Mgeta River Buffer zone showing the names and locations of the four study villages relative to the Wildlife Management Area and the Selous Game Reserve. The crop-damage monitoring programme was carried out in Mbwade. The inset shows the position of the Game Reserve in south-eastern Tanzania. 
shifting, bush-fallow cultivation is practiced there is not a 'hard edge' between the cultivated areas of the village lands and the Wilflife Mamagement Area or Game Reserve. The farmlands of the buffer zone comprise a mosaic of land use types in which cultivated plots are interspersed with fallow plots and areas of natural habitat. At the time of fieldwork, the Gonabisi Open Area was leased to a safari-hunting operator. However, as part of the designated MRBZ Wildlife Management Area, it was also used for procurement of the village wildlife quota.

The MRBZ incorporates the lands of 20 villages, with a low human population density of 28 people per $\mathrm{km}^{2}$ (total population of 47,000, extrapolation from URT, 1990) concentrated in a linear settlement pattern along the district road to Morogoro, such that the majority of the buffer zone villages are located at a distance of $5 \mathrm{~km}$ or more from the game reserve boundary. The population is ethnically mixed and includes a high proportion of immigrants ( $57 \%$ of the survey sample of 202 respondents). With the exception of the Maasai, the ethnic groups present in the area are all agriculturalist by tradition and the predominant economic activity is smallholder farming based on a system of extensive, bushfallow cultivation. The main growing season coincides with the start of the long rains and extends from February to July; a second crop is planted on upland plots at the time of the short November rains for harvest in January. Maize Zea mays, rice Oriza satioum and, to a lesser extent, Sorghum spp., are the main staple crops; cotton Gossypium hirsutum and sesame Sesamum indicum are the main cash crops. Livestock husbandry is not an economic activity of significance for the agriculturalists, and most livestock in the area is owned by Maasai living in separate pastoralist communities. This study therefore focuses on the issue of wildlife crop-damage as perceived and experienced by the agriculturalist villagers of MRBZ.

\section{Methods}

This study is based on data from a household-level questionnaire survey in which MRBZ villagers' perceptions of wildlife crop-damage were examined. Actual patterns of wildlife crop-damage to farm plots were assessed during a 6-month monitoring programme designed to provide semi-quantitative data to cross-check or 'ground-truth' the findings of the questionnaire survey.

\section{The questionnaire survey}

Survey data were collected during August-October 1995. The survey was conducted in four MRBZ villages using a structured questionnaire to ascertain the per- ceived importance of wildlife crop-damage as a constraint on agricultural productivity (Table 1, Q.1), the wildlife species responsible (Q.2 \& Q.3), local people's tolerance of wildlife causing crop-damage (Q.4), and the perceived conflicts of interest between local people and the game reserve (Q.5). The four villages of Gomero, Milengwelengwe, Dakawa and Mbwade, located at distances of 4-8 km from the SGR boundary, were included in the survey. Of these villages, Dakawa and Mbwade have farmlands bordering directly onto the Gonabisi Wildlife Management Area. Households were selected for inclusion in the survey by stratified random sampling, using a list of each village's constituent households. The questionnaire was administered to 202 households, of which $46(22.8 \%)$ were female-headed households, giving a $10.8 \%$ sample of all households present in the study villages. Respondents interviewed for the survey were in most cases the head of household (80.7\%), or the wives of household heads (12.9\%). Twenty-one different ethnic groups were represented in the survey sample, of which the two indigenous ethnic groups, the Kutu and Luguru, made up 51\%, with five other groups, the Ndengereko, Pogoro, Ngindo and Ngoni present as significant minorities.

Survey data are presented as the percentage frequency of respondents giving each response, and so may sum to over $100 \%$ in the case of multi-response questions (Table 1). For the ranking data from questions 1 and 2, a weighted rank index (WRI) is calculated to show the mean rank of each response across the entire sample,

Table 1 Questions asked of Mgeta River Buffer Zone villagers to examine their perceived conflict with wildlife.

1. Which of the following list of problems limit crop yields on your farm? (too much or too little rain/lack of inputs (tractor, fertilisers)/shortage of labour/crop-damage by wildlife/ disease or insect pests/other). Respondents were then asked to rank the problems they reported in order of importance.

2. Which of the following list of wild animals cause crop-damage on your farm? (elephant/hippo/buffalo/warthogs/bushpigs/ baboons/vervet monkeys/rats/other),

Respondents were then asked to rank the four species that caused most damage in order of importance.

3. Respondents who reported large mammal species (elephant, hippo and/or buffalo) as causing crop-damage were then asked:

When was the last time that an elephant/hippo/buffalo caused crop-damage on your farm?

4. Respondents were asked for their response (agree/disagree/ don't know) to the statement: Wild animals that cause crop-damage are pests and should all be shot.

5. Does living next to the Selous Game Reserve cause problems for people in the surrounding villages? If so, what are those problems? 
where $W R I=\sum_{i}^{n}\left(1 / R_{i}\right) / N$, and $n=$ number of respondents ranking problem or species, $R_{i}=$ rank of the ith order, and $N=$ total number of respondents in the sample (after Nepal \& Weber, 1993).

\section{Crop-damage monitoring}

Crop-damage monitoring was carried out from February to late July 1996 for a randomly selected sample of 20 households in Mbwade village. The village had been identified by key informants as a 'hotspot' for cropdamage in the MRBZ due to its location at the edge of the Gonabisi grasslands. Given the constraints of time and manpower available, the monitoring programme could not cover the entire annual production cycle. It was designed to cover the period identified by MRBZ farmers as the annual peak in incidence of on-farm cropdamage at the time of crop-ripening prior to the start of the main harvest. This period coincides with the start of the seasonal movements by large mammals out of the game reserve to seek dry season grazing on the grasslands of the Mgeta river flood-plain. As such, the monitoring programme was designed to provide a descriptive assessment of patterns of wildlife cropdamage on the main staple and cash crop harvest, rather than a quantitative analysis of temporal and spatial variation in damage year-round.

Prior to the start of monitoring, a participatory mapping exercise was carried out in which Mbwade farmers were asked to identify areas of differential risk to wildlife crop-damage within the village agricultural lands. The mapping exercise showed that lowland plots up to $300 \mathrm{~m}$ from the tributary of the Mgeta river that forms the boundary of the village farmlands and the Wildlife Management Area, and upland plots up to $300 \mathrm{~m}$ from the edge of an area of woodland that marked the eastern boundary of the village lands were considered the areas most vulnerable to wildlife crop-damage, whereas central areas of farmland were considered less vulnerable. Field visits showed, however, that as a result of the system of extensive agriculture practiced by the MRBZ villagers, cultivated plots in the central farmland areas were often interspersed with remnant areas of wild habitat or fallow lands, which provided refuge for small to medium-sized wildlife crop pests such as monkeys, baboons Papio anubis and bush pig Potamochoerus porcus. Thus the vulnerability of a farmplot to wildlife crop-damage was a function of both its location relative to the Wildlife Management Area and relative to other cultivated plots, such that plots located within an area of consolidated cultivation in the less vulnerable, central farmland areas, or within the village residential area were considered to be at lower risk of damage. A system of risk categories was therefore drawn up to reflect the vulnerability of farm-plots under cultivation by the 20 households selected for monitoring as a function of this edge effect, rather than simply as a function of distance from the Wildlife Management Area (Table 2).

Data collection for the crop-damage monitoring was carried out by the village agricultural extension officer resident in Mbwade, who visited each household three times a month at 10-day intervals from the time when the crops were planted in February until the end of the harvest in late July. During these visits the household head was asked whether any of his or her plots under cultivation had been damaged by wildlife in the preceding 24 hours. When crop-damage was reported, the respondent was asked to identify the wildlife species responsible, which crop was damaged, and to estimate the area and intensity of damage. The agricultural extension officer then made a field visit to the farm-plot to check for signs of the wildlife species that had caused the damage, and to visually verify the extent and intensity of the damage. For a subset of the crop-damage events reported, the agricultural extension officer's assessment

Table 2 Distribution of monitored farm plots by location in relation to risk categories defined by Mbwade farmers.

\begin{tabular}{|c|c|c|c|c|}
\hline $\begin{array}{l}\text { Risk } \\
\text { category }\end{array}$ & Category description & $\begin{array}{l}\text { No. } \\
\text { plots }\end{array}$ & $\begin{array}{l}\text { Total area } \\
\text { (ha) }\end{array}$ & $\begin{array}{l}\text { Crops } \\
\text { (\% area) }\end{array}$ \\
\hline Low & $\begin{array}{l}\text { Plots in and around the village centre, with no adjacent } \\
\text { natural habitat. }\end{array}$ & 15 & 9.1 & $\begin{array}{l}\text { Maize }(73 \%) \\
\text { Sorghum }(27 \%)\end{array}$ \\
\hline Medium & $\begin{array}{l}\text { Plots in farmlands not bordering the Wildlife Management } \\
\text { Area but }<300 \mathrm{~m} \text { from areas of natural habitat (secondary } \\
\text { regrowth or woodland); edge plots bordering areas of natural } \\
\text { habitat in or near village. }\end{array}$ & 13 & 8.0 & $\begin{array}{l}\text { Maize }(55 \%) \\
\text { Rice }(23 \%) \\
\text { Other }(14 \%) \\
\text { Sorghum }(7 \%)\end{array}$ \\
\hline High & $\begin{array}{l}\text { Plots in farmlands bordering the Wildlife Management Area } \\
\text { with areas of natural habitat (river, bush, woodland) nearby } \\
(<300 \mathrm{~m} \text { away). }\end{array}$ & 23 & 15.4 & $\begin{array}{l}\text { Maize }(20 \%) \\
\text { Rice }(75 \%) \\
\text { Sorghum }(3 \%) \\
\text { Other }(2 \%)\end{array}$ \\
\hline
\end{tabular}


of the extent and intensity of damage caused was crosschecked by SG. Although the tendency for respondents to exaggerate crop losses in the hope of obtaining compensation is a recognized practical problem of cropdamage monitoring, particularly in situations involving outside researchers (Bell, 1984), the village agricultural extension officer was able to integrate the data collection into his routine visits. Because he was well-known and liked by villagers, he was able to ask questions informally, thereby avoiding the use of a formal survey instrument.

Frequency data are presented on the incidence and impact of crop-damage on the farm-plots. A composite index of wildlife damage impact was calculated from the area of damage estimated in four categories $(1=<25 \%$, $2=25-50 \%, 3=>50-75 \%, 4=>75 \%$ of the plot under cultivation) and the intensity of damage in three categories ( 1 =slight, $2=$ moderate, and $3=$ severe), as Wildlife Damage Index $=$ Area category ${ }^{*}$ Intensity category. This is a measure of the scale of impact of wildlife cropdamage events, rather than a quantitative measure of economic losses incurred due to crop-damage.

\section{Results}

\section{Villagers' perceptions of wildlife crop-damage}

Of the 198 households interviewed, 95.5\% reported wildlife crop-damage as a factor limiting crop yields, and $34.8 \%$ of respondents ranked it as the primary constraint on their agricultural productivity. Weighted Rank Index values for perceived constraints on agricultural yield (Table 1, Q1) show that wildlife crop-damage was ranked overall as more important than too much or too little rainfall, lack of inputs such as pesticides or tractor power, or disease and insect pests (Table 3).

The most commonly cited wildlife causing cropdamage in the MRBZ villages were bush pigs, vervet monkeys Cercopithecus aethiops, and rats. These animals were also ranked as causing most damage across the sample as a whole (Table 4). Large mammals, such as elephants Loxodonta africana, buffalo Syncerus caffer, and hippopotamus Hippopotamus amphibious, were ranked as problem animals of lesser importance because,

Table 3 Constraints on agricultural yields (\% frequencies) reported by respondents interviewed during the questionnaire survey ( $n=198$ ), the perceived relative importance of these problems shown by the $\%$ of respondents ranking each as the primary constraint on their productivity, and the overall Weighted Rank Index value (see text for details) for each problem.

\begin{tabular}{llcl}
\hline Constraint & $\begin{array}{l}\text { \% of households reporting } \\
\text { problem }\end{array}$ & $\begin{array}{l}\text { \% of households ranking } \\
\text { problem 1st }\end{array}$ & $\begin{array}{l}\text { Weighted Rank } \\
\text { Index }\end{array}$ \\
\hline Wildlife crop-damage & 95.5 & 34.8 & 0.59 \\
Too much/too little rainfall & 89.4 & 13.6 & 0.38 \\
Lack of inputs (e.g. pesticides) & 74.2 & 18.7 & 0.37 \\
Disease and/or insect pests & 84.8 & 6.6 & 0.33 \\
Shortage of manpower & 63.6 & 10.1 & 0.23 \\
Other $^{1}$ & 27.2 & 0.16 \\
\hline
\end{tabular}

${ }^{1}$ Responses referring to the problems of human sickness, the 'hungry season' and lack of capital or inaccessibility of markets were categorized as 'Other'.

Table 4 Wildlife species reported as being responsible for crop-damage by respondents interviewed during the questionnaire survey $(n=197)$, the perceived relative importance of each species shown by the \% of respondents ranking the species as causing most damage, and the overall Weighted Rank Index values (see text for details) for each species.

\begin{tabular}{|c|c|c|c|}
\hline Species & $\begin{array}{l}\% \text { of households } \\
\text { complaining }\end{array}$ & $\begin{array}{l}\% \text { ranking } \\
\text { species } 1 \text { st }\end{array}$ & $\begin{array}{l}\text { Weighted Rank } \\
\text { Index }\end{array}$ \\
\hline Bush pig Potamochoerus porcus & 89.9 & 32.2 & 0.55 \\
\hline Vervet monkey Cercopithecus aethiops & 75.9 & 13.1 & 0.39 \\
\hline Rats Rattus spp. & 57.8 & 26.6 & 0.38 \\
\hline Baboon Papio anubis & 31.2 & 4.0 & 0.13 \\
\hline Buffalo Syncerus caffer & 30.2 & 4.0 & 0.12 \\
\hline Hippo Hippopotamus amphibius & 31.7 & 1.5 & 0.11 \\
\hline Elephant Loxodonta africana & 15.1 & 3.0 & 0.06 \\
\hline Other $^{1}$ & 23.3 & 2.5 & 0.09 \\
\hline Warthog Phacochoerus africanus & 7.4 & 0.0 & 0.02 \\
\hline
\end{tabular}

${ }^{1}$ Species named by $<5 \%$ of respondents were categorized as 'Other'; this included birds Quelea sp., civet Viverra civetta, cane rat Thryonomys swinderianus and bushbuck Tragelaphus scriptus. 
although they can cause damage to the extent of occasionally destroying entire farm-plots, such incidents of severe damage occur relatively infrequently. Of the respondents $(43.7 \%, n=199)$ who included elephant, buffalo and/or hippo in their ranking of problem animals, the majority $(37.2 \%)$ also reported having experienced large mammal crop-damage on their farms in the 12-month period prior to the survey, albeit mostly as single, isolated incidents.

Consistent with the perception of wildlife cropdamage as having markedly negative impacts on the livelihoods of MRBZ villagers, the survey found widespread intolerance of wildlife; $59.1 \%$ of respondents $(n=193)$ agreed that "Wild animals that cause cropdamage are pests and should all be shot". Wildlife crop-damage was also widely perceived as a direct result of the proximity of the MRBZ villages to the Selous Game Reserve; $46.5 \%$ of all respondents $(n=200)$ complained of conflicts with wildlife, the predominant type being crop-damage (43.0\% of all respondents). Respondents who reported having experienced problems of crop-damage by large mammals in the year prior to the survey were more likely to make this response $\left(\chi^{2}=11.6\right.$, d.f. $\left.=1, P<0.001\right)$. However, $52 \%$ of the respondents who perceived wildlife conflicts as being associated with the game reserve $(n=93)$ had no recent experience of crop-damage by large mammals.

\section{Patterns of wildlife crop-damage recorded during monitoring}

A total of 81 crop-damage events were recorded during the monitoring programme. Across the whole sample, there was a 0.24 probability for a household to report crop-damage on any sampling day. The probability of a household reporting incidents of crop-damage varied, however, over the course of the cropping cycle, rising from 0.05-0.20 during the first weeks after planting in February-March, to 0.30-0.55 during the May-June when the maize and rice crops were producing new seed, and subsequently declining to $0.15-0.20$ in the weeks prior to the harvest in late July.

The monitoring data show a slight tendency for the incidence of crop-damage events to vary in relation to farm plot location. Fewer crop-damage events were recorded on farm plots at locations categorized as low and medium risk (2.94 \pm SE 1.97 and $3.85 \pm$ SE 1.64 events per ha for low-risk and medium-risk plots, respectively), than on farm-plots categorized as high risk locations (5.05 \pm SE 1.16 events per ha). This pattern of spatial variation was not however statistically significant (Kruskal-Wallis $\chi^{2}=4.49$, d.f. $=3, P=0.213$ ). In this respect the monitoring data do not support the local perception that problems of wildlife crop-damage are a function of the proximity of the MRBZ villages to the game reserve.

The distribution of the Wildlife Damage Index scores suggests that most incidents were of slight impact in terms of the scale of crop losses caused, with only a few involving severe widespread damage (Table 5), consistent with the pattern of crop-damage impacts described by Naughton-Treves (1997) along the border of Kibale National Park in Uganda. Analysis of the relative magnitude of crop-damage impacts, as measured by the wildlife damage index, shows that overall most losses were of maize and rice, with relatively little damage to sorghum and other crops. However, if we consider the area of each crop being monitored, a disproportionate amount of damage occurred on farm-plots under maize (51.0\% of all crop-damage on $39.9 \%$ of the total cultivated area, Table 5), as also reported by Naughton-Treves (1997), and 'other' crops (7.8\% of all crop-damage on $4.4 \%$ of the area), while the damage to sorghum was roughly proportional to the area monitored ( $8.5 \%$ of all crop-damage on $9.0 \%$ of the area), and rice was the least damage-prone crop (32.7\% of all crop-damage on $46.7 \%$ of the area).

Most incidents of on-farm crop-damage were caused by small to medium-sized wildlife (bush pigs, vervet

Table 5 Frequency of the scale of impact of recorded crop-damage events, by crop. The sum of the Wildlife Damage Index values (see text for details) shows the relative order of magnitude of losses for each.

\begin{tabular}{lcccc}
\hline & \multicolumn{2}{c}{ Scale of impact ${ }^{1}$} & & \\
\cline { 2 - 4 } Crop & Slight $(\%)$ & Moderate (\%) & Sum of Wildlife Damage Index \\
Maize $(n=35)$ & $20(25.6)$ & $10(12.8)$ & $5(6.4)$ & $78(51.0)$ \\
Rice $(n=23)$ & $17(21.8)$ & $3(3.8)$ & $3(3.8)$ & $50(32.7)$ \\
Sorghum $(n=8)$ & $5(6.4)$ & $2(2.6)$ & $1(1.3)$ & $13(8.5)$ \\
Other $(n=12)$ & $11(14.1)$ & $1(1.3)$ & $0(0.0)$ & $12(7.8)$ \\
All crops $(n=78)$ & $53(67.9)$ & $16(20.5)$ & $9(11.5)$ & $153(100.0)$ \\
\hline
\end{tabular}

${ }^{1}$ Scale of impact categories defined in relation to Wildlife Damage Index scores, where Slight $=1-2$, Moderate $=3-6$ and Severe $=8-12$. 
monkeys or birds) rather than by large mammals (Table 6). Here, there is a difference between the questionnaire survey and monitoring data sets. A high incidence of actual crop-damage events by birds was recorded during monitoring, which may suggest that the perceived contribution of birds as crop-damage agents was underestimated by survey respondents. However, birds were not specifically listed in the question on crop damage agents, but were instead included in the category 'Other'. Of the six incidents of severe and widespread damage recorded during the monitoring, four were caused by bush pig, one by birds, and one by buffalo. Analysis of the relative magnitude of cropdamage impacts by wildlife species shows that most damage was caused by small to medium-sized animals, whereas only $6.6 \%$ of all losses were recorded to have been due to large mammals.

\section{Discussion}

The survey data presented here show that Mgeta River Buffer Zone villagers perceived wildlife crop-damage as a significant constraint on their main economic activity, agricultural production. Survey respondents expressed a marked intolerance of wildlife in the context of this conflict, which was perceived as being due to the situation of the MRBZ villages adjacent to the Selous Game Reserve, despite their relative distance from the actual game reserve boundary. At the same time, however, respondents recognized that on-farm crop-damage was mostly caused by small to medium-bodied wildlife species, such as bush pigs, vervet monkeys, and birds, rather than by large mammals. Data from the monitoring programme confirm the accuracy of local people's understanding of the wildlife species responsible for on-farm crop-damage. The monitoring data indicate, however, that the majority of crop-damage incidents were of limited impact in terms of the magnitude of direct losses incurred.
Comparison of the questionnaire survey and monitoring data suggests a mismatch between local perceptions of wildlife crop-damage in MRBZ and its actual occurrence, such that villagers appeared to over-report the scale of the problem. The perceived association between crop-damage and the game reserve was also inconsistent with the pattern of most damage being caused by smallerbodied wildlife species. Whereas large mammal species tend to undergo competitive exclusion from areas of human activities at human population densities lower than the 27 people per $\mathrm{km}^{2}$ of MRBZ (Matzke, 1975; Parker \& Graham, 1989), smaller crop-raiding species such as bush pigs, vervet monkeys and birds are resilient to disturbance by human activities and are able to coexist with people even in densely settled areas (Newmark et al., 1994). The presence of these species in MRBZ was not therefore a result of the buffer zone's situation adjacent to the SGR. Thus, the observed non-significant effect of distance to the Wildlife Management Area on incidence may reflect the persistence of the prime culprits of crop damage in small 'refuge' areas of natural habitats in and around fields.

To identify the disjunction between the perceived and actual dimensions of crop-damage in MRBZ is not to discount the validity of villagers' representation of the problem. We argue instead that the perceived impacts of crop-damage on local people are an important conservation issue, based on the logic that if local people do not attach a positive value to wildlife they will not support its existence. In this context, the question is not to what extent the MRBZ villagers were right or wrong in their assessment of crop-damage impacts, but why they reported it as such a major source of conflict that was, furthermore, associated with the game reserve, and what factors shaped their perceptions of the problem.

Studies of human-wildlife conflicts around protected areas elsewhere in Sub-Saharan Africa (Marks, 1976; Naughton-Treves, 1996; Siex \& Struhsaker, 1999) and in

Table 6 Frequency of the scale of impact of recorded crop-damage events, by wildlife species responsible. The sum of the Wildlife Damage Index values (see text for details) shows the relative order of magnitude of losses due to each species or category.

\begin{tabular}{|c|c|c|c|c|}
\hline \multirow[b]{2}{*}{ Wildlife species } & \multicolumn{3}{|c|}{ Scale of impact ${ }^{1}$} & \multirow{2}{*}{$\begin{array}{l}\text { Sum of Wildlife Damage Index } \\
\text { scores ( } \% \text { of all damage })\end{array}$} \\
\hline & Slight (\%) & Moderate (\%) & Severe $(\%)$ & \\
\hline Bushpig $(n=37)$ & $21(27.3)$ & $11(14.3)$ & $5(6.5)$ & $84(55.3)$ \\
\hline Birds $(n=13)$ & $10(13.0)$ & $1(1.3)$ & $2(2.6)$ & $27(17.8)$ \\
\hline Vervet monkeys $(n=16)$ & $11(14.3)$ & $4(5.2)$ & $1(1.3)$ & $21(13.8)$ \\
\hline Buffalo $(n=4)$ & $2(2.6)$ & $1(1.3)$ & $1(1.3)$ & $10(6.6)$ \\
\hline Other $(n=9)$ & $8(10.4)$ & $1(1.3)$ & $0(0.0)$ & $10(6.6)$ \\
\hline All species $(n=77)$ & $52(67.5)$ & $16(20.8)$ & $9(7.8)$ & $152(100.0)$ \\
\hline
\end{tabular}

${ }^{1}$ Scale of impact categories defined in relation to Wildlife Damage Index scores, where Slight $=1-2$, Moderate $=3-6$ and Severe $=8-12$. 
Asia (Nepal \& Weber, 1993; Heinen, 1993; Sekhar, 1998) have also shown the tendency of local people to overreport the incidence and impacts of wildlife damage to crops, livestock and property, leading to various explanations of the behaviour. Based on a quantitative study of patterns of wildlife crop-damage in villages bordering Uganda's Kibale National Park, NaughtonTreves (1996) suggested that local perceptions of cropdamage tend to be disproportionately shaped by extreme damage events. This tendency appears to provide a partial explanation for the observed discrepancy between perceived and actual patterns of crop-damage in MRBZ, in that survey respondents who had recently experienced crop-damage by large mammals were more likely to report it as a problem of living next to the game reserve. It does not however account for the views of the survey respondents who had not experienced any recent cropdamage by large mammals, but who nevertheless reported the problem as being due to their proximity to the game reserve.

As documented in studies from Uganda (NaughtonTreves, 1996; Hill, 1997) and Zambia (Marks, 1976), smallholder farmers at risk of wildlife crop-damage often adopt a strategy of guarding their farm plots to minimize losses. This was common practice in MRBZ, where the majority of households moved out of the village during the high-risk months of May and June to live in temporary shelters on their farm-plots to ensure round the clock protection of their crops. Anecdotal data, whereby the few incidents of severe crop-damage recorded during fieldwork occurred without exception on plots that were left unguarded, supports the need for, and effectiveness of, this strategy. The investment of time and labour required to ensure effective protection against wildlife crop-damage represented considerable opportunity costs to MRBZ farmers. Although it is to be expected that these opportunity costs contributed to villagers' negative perceptions of the problem, they still do not explain the association of wildlife crop-damage with the SGR.

Instead, this perception is better understood in relation to the tenure arrangements for wildlife in Tanzania which, under legislation prevailing at the time of the study, was owned by the state (MTNRE, 1995). The MRBZ villagers accordingly felt that authority and responsibility for wildlife lay with the state, and viewed the SGR, rightly, as a protected area for the state-owned wildlife resource (Gillingham \& Lee, 1999). Although implementation of the MRBZ community wildlife management initiative had given villagers access to some wildlife-related benefits, primarily in the form of meat from the village wildlife quota, at the time of fieldwork the Tanzanian Department of Wildlife retained decision-making authority for wildlife management in the buffer zone, the major benefits of which still went to the state in the form of safari-hunting revenues (Price-Waterhouse, 1996). As villagers did not have property rights for the wildlife on village lands, they did not have authority to take direct action against animals causing crop-damage, and were dependent on the District Game Scouts for the control of problem animals. State proprietorship of the resource meant in effect that MRBZ villagers had little direct influence over the costs and benefits incurred due to their coexistence with wildlife, and so represented an important factor shaping local vulnerability to cropdamage (see also Naughton-Treves, 1997, on this point). Since the fieldwork for this study the Tanzanian government has formally endorsed a policy of community-based conservation based on the establishment of Wildlife Management Areas in which local people have use rights over wildlife and natural resources as the principal mechanism for wildlife management outside protected areas (URT, 1990). Under the new policy, the scope for the establishment of tenure arrangements that empower local people to take a more active role in wildlife management is significantly increased, although to date implementation of the procedures for establishment of Wildlife Management Areas has proven time-consuming.

In the context of state ownership of the resource, the prevalent over-reporting of crop-damage observed in MRBZ can be understood as a form of passive resistance to the costs of living with wildlife and villagers' curtailed access to the resource. As wildlife had yet to become a resource of significant positive value to buffer zone residents, villagers adopted a strategy of disproportionate complaint in trying to redress the imbalance of power, seeking to influence wildlife management interventions by Department of Wildlife personnel in their favour. A similar underlying logic of protected area-people relationships is described by Bergin (1995) from a case study of the community conservation initiative around Arusha National Park in Tanzania, and by NaughtonTreves (1996) in Uganda. Naughton-Treves in particular emphasizes the issue of proprietorship as a factor influencing local perceptions of crop-damage, based on her finding that "livestock damage to crops is comparable or exceeds that caused by many wildlife species", but is rarely a source of complaint because livestock are perceived as providing benefits to local people, and victims of damage by livestock belonging to another party have the right to demand compensation (Naughton-Treves, 1996). We conclude therefore that the nature of the relationship between the Department of Wildlife and local people in MRBZ, whereby villagers perceive themselves as marginalized from the management of the wildlife resource, is an important factor contributing to the strongly negative perception of wildlife crop-damage in the area. 
The findings of this study have significant implications for the design and management of projects that aim to promote conservation with development based on community participation in wildlife management. These are: (i) that understanding the nature and costs of humanwildlife conflicts requires the combined assessment of both the perceived and actual dimensions of the problem, and (ii) that ever-increasing investments in conventional 'solutions' to human-wildlife conflict such as fencing or problem-animal shooting will not necessarily resolve the problem, particularly when the wildlife species involved are small to medium-sized and/or commensal species (Newmark et al., 1994). Instead, mitigation of problems of human-wildlife conflict will require pragmatic approaches based on the establishment of transparent, equitable co-management partnerships between local people in rural settlements and higher-level wildlife management authorities.

\section{Acknowledgements}

We thank the Tanzanian Department of Wildlife and the staff of the Selous Conservation Programme and Game Reserve for their support during this study, and the MRBZ villagers for their time and friendship. Saidi Kabanda and Bwana Mbagga of Mbwade village both provided invaluable assistance during the fieldwork. The research in Tanzania was funded by a Quartercentenary Research Scholarship held by S. Gillingham at Emmanuel College, Cambridge University, and additional grants from the Worts Travelling Fund and Smuts Memorial Fund, Cambridge University.

\section{References}

Ardhi Institute. (1991) Village Development Planning for 16 Villages Bordering the Selous Game Reserve in Morogoro South District. Unpublished Report, Selous Conservation Programme, Dar es Salaam, Tanzania.

Baldus, R.D. (1991) Community wildlife management around the Selous Game Reserve. Selous Conservation Programme Discussion Paper, 12. Selous Conservation Programme, Dar es Salaam, Tanzania.

Bell, R.H.V. (1984) The man-animal interface: an assessment of crop damage and wildlife control. In Conservation and Wildlife Management in Africa. (eds R.H.V. Bell \& E. McShane-Caluzi), pp. 389-415. US Peace Corps Office of Training and Program Support, Malawi.

Bergin, P. (1995) Conservation and development: the institutionalisation of community conservation in Tanzanian national parks. PhD thesis, University of East Anglia, Norwich, UK.

Gillingham, S. \& Lee, P.C. (1999) Community wildlife management around the Selous Game Reserve, Tanzania: the impact of wildlife-related benefits on the conservation attitudes of local people. Environmental Conservation, 26, $218-228$.
Gillingham, S. (1998) Giving wildlife value: a case study of community wildlife management around the Selous Game Reserve, Tanzania. PhD thesis, University of Cambridge, Cambridge, UK.

Heinen, J.T. (1993) Park-people relations in Kosi Tappu Wildlife Reserve, Nepal: a socioeconomic analysis. Environmental Conservation, 20, 25-34.

Hill, C.M. (1997) Crop-raiding by wild vertebrates: the farmer's perspective in an agricultural community in western Uganda. International Journal of Pest Management, 43, 77-84.

Kangwana, K.F. (1993) Conservation and conflict: elephant-Maasai interaction in Amboseli, Kenya. PhD thesis, University of Cambridge, Cambridge, UK.

Kiss, A. (1990) Living with wildlife: wildlife resource management with local participation in Africa. World Bank Technical Paper, 130. World Bank, Washington, DC, USA.

Marks, S.A. (1976) Large Mammals and a Brave People: Subsistence Hunters in Zambia. University of Washington Press, Seattle, USA.

Matzke, G.D. (1975) Large mammals, small settlements, and big problems: a study of overlapping space preferences in southeastern Tanzania. PhD thesis, Syracuse University, New York, USA.

MTNRE. (1995) A Review of the Wildlife Sector in TanzaniaVol. 1: Assessment of the Current Situation. Ministry of Tourism, Natural Resources and Environment, Dar es Salaam, Tanzania.

Murphree, M.W. (1993) Communities as institutions for resource management. Typescript, National Conference on Environment and Development, Maputo, Mozambique, 1991. Presented at National Conference on Environment and Development, Maputo, Mozambique.

Naughton-Treves, L. (1997) Farming the forest edge: vulnerable places and people around Kibale National Park, Uganda. The Geographical Review, 87, 27-46.

Naughton-Treves, L. (1996) Uneasy neighbours: wildlife and farmers around Kibale National Park, Uganda. PhD thesis, University of Florida, Florida, USA.

Nepal, S.K. \& Weber, K.E. (1993) Struggle for Existence. ParkPeople Conflict in the Royal Chitwan National Park, Nepal. Asian Institute of Technology, Bangkok, Thailand.

Newmark, W.D., Manyanza, D.N., Gamassa, G.M. \& Sariko, H.I. (1994) The conflict between wildlife and local people living adjacent to protected areas in Tanzania: human density as a predictor. Conservation Biology, 8, 249-255.

Parker, I.S.C. \& Graham, A.D. (1989) Men, elephants and competition. Symposium of the Zoological Society of London, 61, 241-252.

Parry, D. \& Campbell, B. (1992) Attitudes of rural communities to animal wildlife and its utilization in Chobe Enclave and Mababe Depression, Botswana. Environmental Conservation, 19, 245-252.

Price-Waterhouse. (1996) Financial Potential of the Selous Game Reserve and its Buffer Zones. Unpublished Report, Selous Conservation Programme/Department of Wildlife, Dar es Salaam, Tanzania.

Rodgers, W.A. \& Lobo, J.D. (1982) Elephant control and legal ivory exploitation: 1920-1976. Tanganyika Notes and Records, $85,25-54$. 
SCP Project Brief (1994) Selous Conservation Programme Project Brief. Project Report, Gesellschaft für Technische

Zusammenarbeit/Department of Wildlife, Dar es Salaam, Tanzania.

Sekhar, N.U. (1998) Crop and livestock depredation caused by wild animals in protected areas: the case of Sariska Tiger Reserve, Rajasthan, India. Environmental Conservation, 23, $160-171$.

Siex, K.S. \& Struhsaker, T.T. (1999) Colobus monkeys and coconuts: a study of perceived human-wildlife conflicts. Journal of Applied Ecology, 36, 1009-1020.

TWCM. (1995) Aerial Survey of the Selous Game Reserve, Mikumi National Park, and Surrounding Areas: Dry Season 1994. Report, Tanzania Wildlife Conservation Monitoring Unit, Arusha, Tanzania.

URT. (1990) United Republic of Tanzania, 1988 Population Census: Morogoro Regional Profile. Report, Bureau of Statistics, Planning Commission, Dar es Salaam, Tanzania.

Weladji, R.B. \& Tchamba, M.N. (2003) Conflict between people and protected areas within The Bénoué Wildlife Conservation Area, North Cameroon. Oryx, 37, 72-79.
Western, D., Wright, R.M. \& Strum, S.C. (eds) (1994) Natural Connections: Perspectives in Community-based Conservation. Island Press, Washington, DC, USA.

\section{Biographical sketches}

Sarah Gillingham has research interests in the development and implementation of participatory approaches for natural resource management and community-based conservation. Over the past 10 years she has conducted long-term, fieldbased research on protected area-people relationships in Brazilian Amazonia and Tanzania.

Phyllis Lee has conducted field work on African mammals for the past 25 years, and has a research interest in how human attitudes and changing land use patterns affect conservation priorities and effectiveness. 